University of Nebraska - Lincoln

DigitalCommons@University of Nebraska - Lincoln

Nebraska Cooperative Fish \& Wildlife Research Nebraska Cooperative Fish \& Wildlife Research Unit -- Staff Publications

2011

\title{
Nest Predation And Circulating Corticosterone Levels Within And Among Species
}

\author{
Joseph J. Fontaine \\ University of Montana - Missoula, jfontaine2@unl.edu \\ Elena Arriero \\ Universidad Complutense de Madrid, elena.arriero@bio.ucm.es \\ Hubert Schwabl \\ Washington State University, huschwabl@wsu.edu \\ Thomas E. Martin \\ University of Montana - Missoula, tom.martin@umontana.edu
}

Follow this and additional works at: https://digitalcommons.unl.edu/ncfwrustaff

Fontaine, Joseph J.; Arriero, Elena; Schwabl, Hubert; and Martin, Thomas E., "Nest Predation And Circulating Corticosterone Levels Within And Among Species" (2011). Nebraska Cooperative Fish \& Wildlife Research Unit -- Staff Publications. 109.

https://digitalcommons.unl.edu/ncfwrustaff/109

This Article is brought to you for free and open access by the Nebraska Cooperative Fish \& Wildlife Research Unit at DigitalCommons@University of Nebraska - Lincoln. It has been accepted for inclusion in Nebraska Cooperative Fish \& Wildlife Research Unit -- Staff Publications by an authorized administrator of DigitalCommons@University of Nebraska - Lincoln. 


\title{
NEST PREDATION AND CIRCULATING CORTICOSTERONE LEVELS WITHIN AND AMONG SPECIES
}

\author{
Joseph J. Fontaine ${ }^{1,4}$, Elena Arriero ${ }^{1,5}$, Hubert Schwabl ${ }^{2}$, And Thomas E. Martin ${ }^{3}$ \\ ${ }^{1}$ Montana Cooperative Wildlife Research Unit, and the Department of Ecosystem and Conservation Sciences, \\ University of Montana, Missoula, MT 59812 \\ ${ }^{2}$ School of Biological Sciences, Washington State University, Pullman, WA 99164 \\ ${ }^{3}$ U.S. Geological Survey, Montana Cooperative Wildife Research Unit, University of Montana, Missoula, MT 59812
}

\begin{abstract}
Variation in the risk of predation to offspring can influence the expression of reproductive strategies both within and among species. Appropriate expression of reproductive strategies in environments that differ in predation risk can have clear advantages for fitness. Although adult-predation risk appears to influence glucocorticosteroid levels, leading to changes in behavioral and life-history strategies, the influence of offspring-predation risk on adult glucocorticosteroid levels remains unclear. We compared total baseline corticosterone concentrations in Gray-headed Juncos (Junco hyemalis dorsalis) nesting on plots with and without experimentally reduced risk of nest predation. Despite differences in risk between treatments, we failed to find differences in total baseline corticosterone concentrations. When we examined corticosterone concentrations across a suite of sympatric species, however, higher risk of nest predation correlated with higher total baseline corticosterone levels. As found previously, total baseline corticosterone was negatively correlated with body condition and positively correlated with date of sampling. However, we also found that corticosterone levels increased seasonally, independent of stage of breeding. Nest predation can alter the expression of birds' reproductive strategies, but our findings suggest that total baseline corticosterone is not the physiological mechanism regulating these responses.
\end{abstract}

Key words: calendar effect, corticosterone, life history, nest predation, parental care.

\section{Variación Intra- e Interespecífica en la Tasa de Depredación en Nido y Niveles Circulantes de Corticosterona}

Resumen. El riesgo de depredación sobre la descencendia puede tener influencia en la expresión de estrategias reproductivas a nivel intra- e interespecífico. Adecuar la expresión de estrategias reproductivas a condiciones ambientales con diferente riesgo de depredación puede resultar ventajoso en términos de "fitness" o eficacia biológica. El riesgo de depredación sobre individuos adultos parece influir en los niveles circulantes de glucocorticoides, y ocasionar cambios en el comportamiento y en aspectos relacionados con la estrategia de vida. Sin embargo, no está claro aún, cual es el efecto que puede causar el riesgo de depredación sobre la descendencia en los niveles de glucocorticoides de los adultos. En este estudio comparamos los niveles basales de corticoterona en pollos de Junco hyemalis dorsalis en bosques en los que controlamos de manera experimental el riesgo de depredación. A pesar de que nuestro experimento tuvo un efecto importante reduciendo el riesgo de depredación en nido en las parcelas experimentales, no encontramos diferencias significativas en los niveles basales de corticosterona entre los pollos de parcelas experimentales y control. Sin embargo, cuando examinamos la variación en niveles de corticosterona en adultos de un grupo de especies simpátricas, encontramos correlación positiva entre el riesgo de depredación en el nido y los niveles basales de corticosterona. En línea con resultados de otros estudios previos, encontramos que los niveles basales de corticosterona se correlacionaban negativamente con el tamaño corporal y positivamente con la fecha, aunque la correlación con la fecha fue independiente del estadío reproductivo en que se encontrasen los individuos. La depredación en nido puede alterar la expresión de estrategias reproductivas en aves, sin embargo nuestro estudio sugiere que los niveles basales de corticosterona no son el mecanismo fisiológico que regula estas respuestas.

\section{INTRODUCTION}

The extent to which individuals invest in current reproduction is influenced by a variety of extrinsic and intrinsic sources of selection. In particular, sources of mortality, either to offspring or parents, are known to influence parental effort (Roff 1992,
Ghalambor and Martin 2001, Fontaine and Martin 2006a). Yet the physiological mechanisms underlying these patterns are less well known (Sinervo and Svensson 1998, Ketterson and Nolan 1999). An understanding of the physiological processes underlying adjustments in parental effort is paramount

Manuscript received 14 February 2011; accepted 23 April 2011.

${ }^{4}$ Current address: U.S. Geological Survey, Nebraska Cooperative Fish and Wildlife Research Unit, and School of Natural Resources, University of Nebraska, Lincoln, NE 68583.E-mail: jfontaine2@unl.edu

${ }^{5}$ Current address: Department of Zoology and Physical Anthropology, School of Biology, Universidad Complutense de Madrid, Madrid E-28040, Spain

The Condor, Vol. 113, Number 4, pages 825-833. ISSN 0010-5422, electronic ISSN 1938-5422. @ 2011 by The Cooper Ornithological Society. All rights reserved. Please direct all requests for permission to photocopy or reproduce article content through the University of California Press's Rights and Permissions website, http://www.ucpressjournals.com/ reprintInfo.asp. DOI: $10.1525 /$ cond.2011.110027 
to understanding the evolution of life histories and parental care, as well as the management and conservation of species (Clutton-Brock 1991, Sinervo and Svensson 1998, Ketterson and Nolan 1999, Martin 2002, Ricklefs and Wikelski 2002, Barnes and Patridge 2003, Wikelski and Cooke 2006). The hypothalamus-pituitary-adrenal axis is a major component of the endocrine system, which regulates many body processes and may serve to mediate tradeoffs between risk of mortality and reproductive effort (Ricklefs and Wikelski 2002, Wingfield and Sapolsky 2003, Hau et al. 2010). However, despite the importance of the hypothalamus-pituitary-adrenal axis in phenotypic expression, broad experimental studies of its role in the expression of reproductive strategies in alternative environments remain limited (Clinchy et al. 2004, Bonier et al. 2009).

Nest predation is the primary cause of reproductive failure for most birds (Ricklefs 1969, Martin 1995) and thus represents an important source of selection acting on the expression of reproductive strategies. Indeed, correlative studies, as well as recent experimental tests (reviewed in Lima 2009, Martin and Briskie 2009), have shown that parents adjust reproductive strategies in response to the risk of nest predation, yet the physiological mechanisms mediating these responses remain unclear. In birds, exposure to adult predators can lead to elevated secretion of corticosterone (Silverin 1998, Wingfield et al. 1998, Cockrem and Silverin 2002), a steroid hormone involved in regulating metabolic, immune, and stress responses of birds and other vertebrates. Elevated corticosterone levels are thought to facilitate behavioral responses to food stress or predation risk (Wingfield et al. 1998); however, predation on offspring represents an indirect cost to adults and therefore may be mediated differently (Wingfield 2003). Work on the Common Stonechat (Saxicola torquatus) and Song Sparrow (Melospiza melodia) has demonstrated that circulating corticosterone levels are positively related to nest-predator abundance and negatively related to reproductive success and parental effort (Scheuerlein et al. 2001, Zanette et al. 2003, Clinchy et al. 2004). Unfortunately, although these studies found that nest predation differed by site, adult-predation risk may also have differed (Butler et al. 2009). Thus differences in corticosterone levels between sites may reflect differences in the predation risk of adults, offspring, or both. Furthermore, the Stonechat and Song Sparrow studies focused on fathers, which in passerine birds generally play a lesser role in the expression of reproductive strategies than mothers. Given the importance of nest predation and its influence on reproductive strategies (Lima 2009, Martin and Briskie 2009), the question remains whether the avian hypothalamus-pituitary-adrenal axis is truly sensitive to differences in nest-predation risk and ultimately whether corticosterone can mediate changes in avian reproductive strategies.

We explored the potential for the hypothalamus-pituitary-adrenal axis to mediate nest-predation risk in a manner similar to adult-predation risk by measuring total baseline corticosterone (TBC) concentrations of six co-occurring passerines to assess whether differences in nest-predation risk predict differences among species in TBC and subsequent reproductive strategies. In the same system we then experimentally reduced nest-predation risk to test whether TBC concentrations of one species, the Gray-headed Junco (Junco hyemalis dorsalis), were reduced in safer nesting environments independent of adults' predation risk.

\section{METHODS}

\section{STUDY AREA AND SPECIES}

We studied birds breeding in 20 snowmelt drainages located along the Mogollon Rim in central Arizona from 1987 to 2004. Vegetation at the study site is typical of a western mixed conifer forest (Martin 1998). This system is particularly appropriate because nest predation accounts for $98 \%$ of nest failure (Martin 1998) and therefore should impose direct selection on the expression of reproductive strategies and the proximate mechanisms that regulate them.

We examined TBC levels of nesting Gray-headed Juncos on a series of paired plots with and without experimental removal of nest predators (see next). In addition, we examined females of five other species breeding at the same site to determine if differences among species in nest-predation risk predicted differences in TBC concentrations. We then tested whether TBC levels predicted differences in parental care behaviors and life-history traits (see next section).

\section{REMOVAL OF NEST PREDATORS}

From 2001 to 2004 we conducted an experiment to alter nestpredation risk across the landscape by removing predators from 10 plots to be compared with 10 neighboring control plots with intact predator communities (see Fontaine and Martin 2006a for detailed description). Each plot is an individual drainage with similar vegetation composition and structure, separated from other drainages by ridges of different habitat (Martin 1998). We paired plots on the basis of 20 years of prior data that suggested similar assemblages of birds, predators of adults, predators of nests, and plant assemblages and removed nest predators from ten drainages of 5-10 ha. Control and removal plots were paired to minimize possible spatial influences but were separated by at least one intervening drainage to buffer against possible carryover effects of removals on control plots. We removed mammalian predators by live trapping and transporting individuals $>10 \mathrm{~km}$ to locations separated from the study area by large canyons; however, because of their mobility avian predators were removed lethally (Fontaine and Martin 2006a). We removed predators from the same plots each year to maximize effect size.

Removals began before females of migratory species arrived at the study site and continued throughout the breeding season. The primary nest predators removed were the red squirrel (Tamaiasciurus hudsonicus), gray-neck chipmunk 
(Eutamias cinereicollis), deer mouse (Peromyscus maniculatus), white-footed mouse (P. leucopus), and Steller's Jay (Cyanocitta stelleri). These predators influence nest-predation rates significantly (Martin 1998) but represent no threat to adult birds; therefore, any differences between treatments in TBC levels reflect risk to offspring and not adult mortality. To evaluate the efficacy of removals, we measured nest-predation rates and assessed nest-predator abundance throughout the breeding season with aural surveys for Steller's Jays and squirrels (Fontaine and Martin 2006a).

\section{NEST FINDING AND MONITORING}

We located and monitored nests by long-standing techniques (Martin and Geupel 1993), but we were careful to limit human disturbance so as to not influence TBC levels inadvertently. Whenever possible, we checked nests from afar by observing parental behavior or when females were off during normal foraging. From the outcomes of nest visitations we calculated daily mortality rates of nests for both treatments and compared them across years with a paired $t$-test (Mayfield 1961, 1975, Hensler and Nichols 1981; see Fontaine and Martin 2006a for details). To assess the potential for nest predation to lead to differences among species in TBC levels we used data from a much broader sample gathered from 1987 to 2004 to make estimates of daily nest-predation risk more robust for each species.

\section{LIFE HISTORY AND PARENTAL CARE TRAITS}

We measured the mass of eggs in nests located during nest building or egg laying, weighing them within 2 days of clutch completion with a calibrated digital scale accurate to $0.001 \mathrm{~g}$. We recorded clutch size for any nests found prior to hatching because partial losses are rare in this system (Fontaine, pers. obs.). We assessed parental behaviors by filming nests for approximately $6 \mathrm{hr}$ starting within $30 \mathrm{~min}$ of sunrise by using a Sony Handycam video camera concealed near the nest (Martin et al. 2000). Tapes were scored for behaviors including the percentage of time the female spent on the nest (nest attentiveness) and the rate the male visited the nest to feed the incubating female (mate-feeding rate).

\section{CAPTURE AND HANDLING TECHNIQUES}

In 2004 we captured and bled a subset of parent birds. We were careful to limit our samples to nests assumed to be first attempts on the basis of nesting history within the territory. All individuals were captured with a 6-m net set within 2-4 m of nests. Females were flushed from the nest while incubating or captured while returning to incubate. Males were captured while returning to the nest to feed nestlings. All birds were captured from 0600 to 1200 , and blood samples were collected within approximately $3 \mathrm{~min}$ of capture, a delay that can be considered to reflect TBC concentrations across a variety of species (Romero and Reed 2005) and juncos specifically (Schoech et al. 1999). We obtained blood samples $(\sim 50 \mu \mathrm{L})$ from the brachial vein with heparinized microcapillary tubes. Blood was kept on ice in small coolers for no more than $4 \mathrm{hr}$ before it was centrifuged and the plasma was frozen for future analysis. We also measured body mass with a $30-\mathrm{g}$ spring scale accurate to $0.5 \mathrm{~g}$ and tarsus length with a digital caliper accurate to $0.01 \mathrm{~mm}$. We used morphological measurements to develop a scaled mass index to estimate body condition (Peig and Green 2009): $\hat{M}_{i}=M_{i}\left[\frac{T_{o}}{T_{i}}\right]_{\text {SMM }}^{b_{\text {SW }}}$, where $M_{i}$ and $T_{i}$ are the mass and tarsus measurements of the individual, $b_{S M A}$ is the scaling exponent estimated by the regressing of mass and tarsus for all individuals in the population, and $T_{0}$ is the population mean for tarsus length.

\section{CORTICOSTERONE MEASUREMENTS}

We measured TBC in plasma samples ranging from 10 to $20 \mu \mathrm{L}$ (average $13 \mu \mathrm{L}$ ) in one radioimmunoassay with a sensitivity of $1.1 \mathrm{ng} \mathrm{mL}^{-1}$ plasma (intra-assay coefficient of variation $5.7 \%)$. For the assay, tritiated corticosterone $(2000 \mathrm{Ci}$ $\mathrm{min}^{-1}$ ) was added to each plasma sample for estimation of recoveries (mean $76 \%$ ), and samples were allowed to equilibrate overnight at $4{ }^{\circ} \mathrm{C}$. Steroids were extracted with $2 \times 4 \mathrm{~mL}$ of petroleum ether and diethylether (3:7 by volume) in minicolumns, and extracts were dried at $37^{\circ} \mathrm{C}$ over a stream of $\mathrm{N}_{2}$. We performed assays following protocols developed by Schwabl (1995), using corticosterone antibody B3-163 (Esoterix Endocrinology, Inc.). All methods were approved and monitored under permits from the Arizona Game and Fish Department (SP635085), the U.S. Fish and Wildlife Service (MB7911013), and the University of Montana Institutional Animal Care and Use Committee (01-04-TMCWR-033105-01).

\section{STATISTICAL ANALYSES}

We tested for differences in TBC among females of different species with a general linear model that included species as a factor and body condition, sampling date, and sampling time as covariates, from which we estimated marginal means for each species. We tested for difference among species with post-hoc tests of least significant difference (LSD) and used the estimated marginal means to examine whether nest-predation risk predicted differences among species in $\mathrm{TBC}$ and whether TBC in turn predicted differences in behavioral and life-history traits. Tests of behavioral and life-history traits were corrected with a sequential Bonferroni adjustment for multiple tests.

To test for proximate responses to nest-predation risk we compared TBC levels by treatment for incubating female juncos and males feeding nestlings with a general linear model that included treatment and sex as factors and body condition, sampling date, and sampling time as covariates.

To ensure that assumptions of normality were met, we natural-log-transformed TBC concentrations and used the transformed variable in all models and figures presented here. 
For all tests we initially tested for interactions but removed insignificant findings from models.

\section{RESULTS}

We collected samples from 65 incubating females, 12 of the Orange-crowned Warbler (Oreothlypis celata), 14 of the Red-faced Warbler (Cardellina rubrifrons), 22 of the Gray-headed Junco, 5 of the Hermit Thrush (Catharus guttatus), 8 of the Cordilleran Flycatcher (Empidonax occidentalis), and 4 of the House Wren (Troglodytes aedon). Pooled across species, TBC levels were sensitive to body condition and sampling date but were unrelated to sampling time (Fig. 1; species: $F_{5,64}=2.095, P=0.080$; date: $F_{1,64}=6.971, P=0.011$; time: $F_{1,64}=0.357, P=0.553$; condition: $F_{1,64}=4.960, P=0.030$; interactions not significant). On the basis of an LSD post-hoc test of estimated marginal means, Gray-headed Juncos and Hermit Thrushes had TBC levels significantly higher than those of all other species (Fig. 2a). Differences among species in TBC were significantly correlated with among species differences in nest-predation risk (Fig. $2 \mathrm{~b} ; F_{1,5}=14.628$, $P=0.019$ ). After multiple tests were controlled for, TBC predicted body mass (Fig $3 \mathrm{a} ; F_{1,5}=226.941, P<0.001$ ) but none of the other life history or behavioral traits (Fig $3 ; F_{1,5} \leq 12.838, P \geq 0.115$ ).

Over 4 years we removed 3791 predators from removal plots (Fontaine and Martin 2006a), resulting in a 13\% drop in daily capture rates of predators, a $72 \%$ average decline in predator detections (Fontaine and Martin 2006a), and ultimately a $40 \%$ decline in daily nest predation for incubating juncos (removal, $0.03 \pm 0.01$; control, $0.05 \pm 0.01 ; t_{3}=-2.654$, $P=0.039$ ), which is consistent with previous examinations of a broader set of species (Fontaine and Martin 2006a,b).

We successfully sampled TBC in 23 female (16 control, 7 removal) and 10 male (6 control, 4 removal) juncos. Despite clear differences in nest-predator abundance, predator cues, and corresponding nest-predation risk, TBC levels did not differ by treatment or sex (female: control $=1.33 \pm 0.18$, removal $=1.35 \pm 0.28 ;$ male: control $=1.08 \pm 0.29$, removal $=$ $1.18 \pm 0.36)$. The relationship of date, however, remained significantly positive (treatment: $F_{1,32}=0.032, P=0.859$; sex: $F_{1,32}=0.670, P=0.420$; date: $F_{1,32}=5.347, P=0.029$; condition: $F_{1,32}=2.316, P=0.140$; time: $\left.F_{1,32}=0.437, P=0.514\right)$.

\section{DISCUSSION}

Predation is a major ecological and evolutionary force that clearly shapes the expression of behavioral and life-history traits both within and among species (Roff 1992, Martin 1995, Begon et al. 1996, Pianka 2000). Moreover, behavioral and life-history traits shift in response to changes in nest-predation risk (Ghalambor and Martin 2002, Doligez and Clobert 2003, Fontaine and Martin 2006a,b, Lima 2009, Martin and Briskie 2009), and glucocorticosteroids are a potential physiological mechanism mediating these responses (Scheuerlein et al. 2001, Clinchy et al. 2004). Despite a clear decrease in nest-predation risk and corresponding changes in reproductive strategies (Fontaine and Martin 2006a,b), TBC concentrations did not differ by nest-predator treatment, suggesting that TBC may not be the mechanism regulating adaptive responses to nest-predation risk. Our results may initially appear surprising given the correlative (Scheuerlein et al. 2001, Clinchy et al. 2004) and experimental (Silverin 1998, Cyr and Romero 2007) studies suggesting otherwise, but previous examinations of the relationship between nest predation and the hypothalamic-pituitary-adrenal axis have failed to differentiate between threats to offspring and threats to parents (Butler et al. 2009). By manipulating the nest-predator community only, we demonstrated that differences in environmental mortality risk to offspring did not to lead to differences in TBC levels,

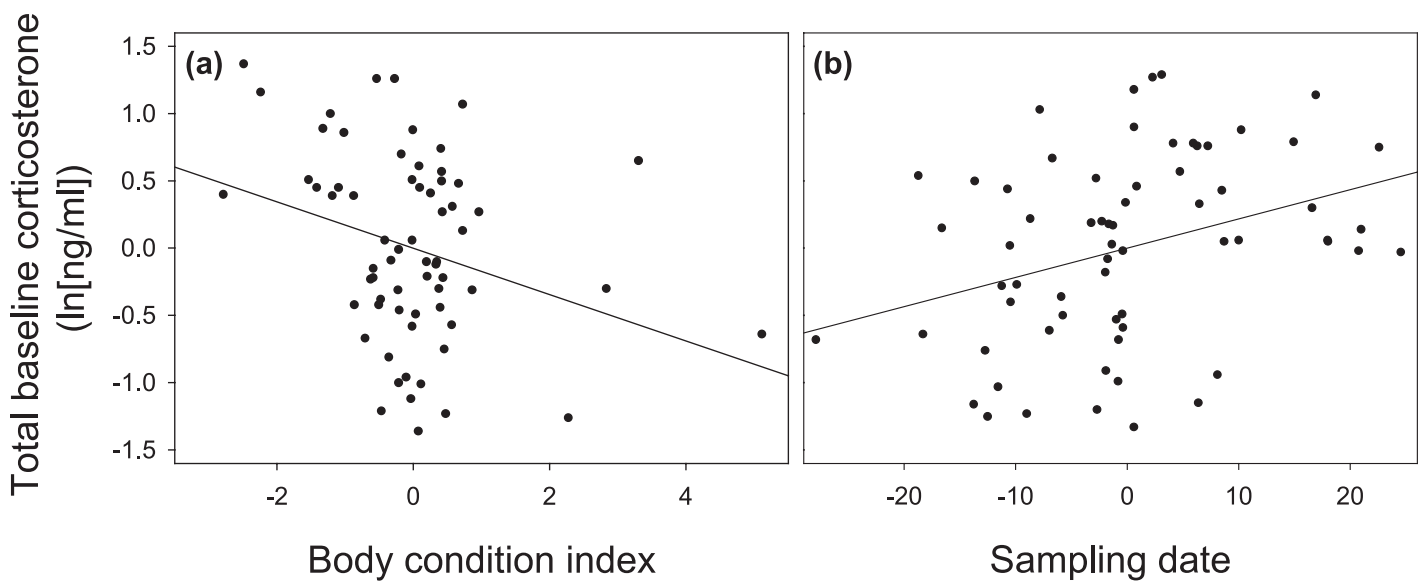

FIGURE 1. Total baseline corticosterone levels were influenced by body condition and sampling date. Across the six species sampled, (a) incubating females that were in better condition had lower TBC levels, while (b) females that were sampled later in the breeding season had higher TBC levels. Data are presented as partial regression plots displayed as unstandardized residuals from a linear model after control for species effects as well as sampling date and body condition, respectively. 

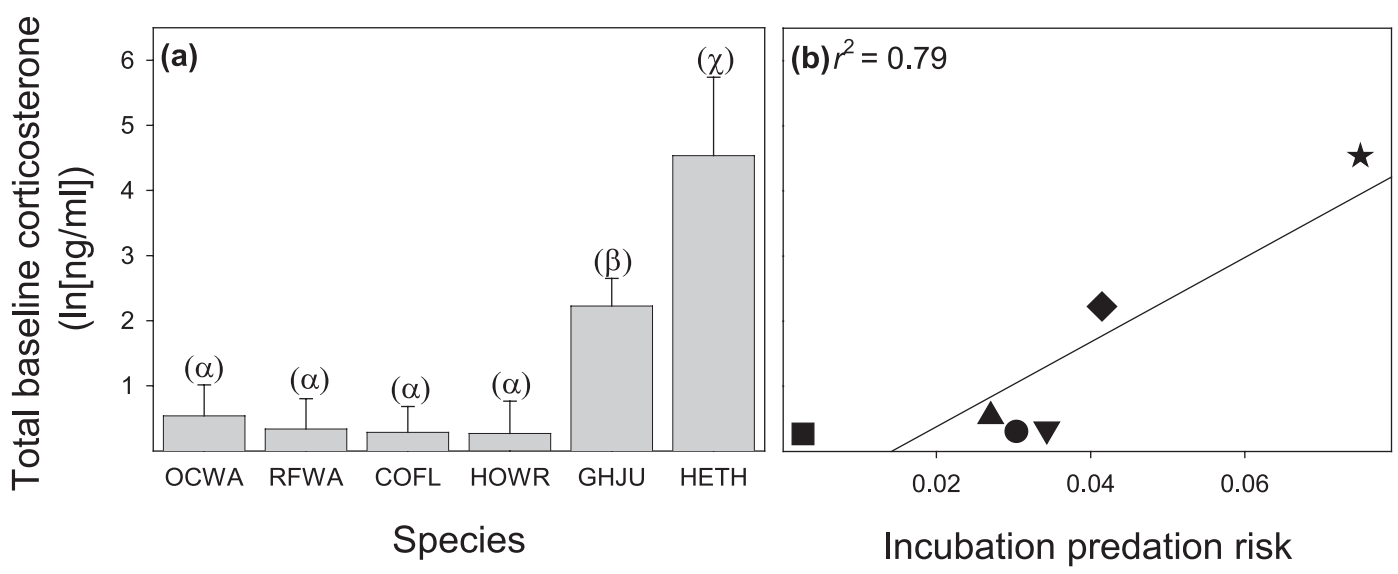

FIGURE 2. Total baseline corticosterone levels differed by species as predicted by differences in nest-predation risk. $\boldsymbol{\Delta}$, Orange-crowned Warbler (OCWA, 12); $\boldsymbol{\nabla}$, Red-faced Warbler (RFWA, 14); 9 , Cordilleran Flycatcher (COFL, 8); $\mathbf{\square}$, House Wren (HOWR, 4); headed Junco (GHJU, 22); Hermit Thrush (HETH, 5). Incubating females differed in TBC levels by species (a) in strong association with differences among species in nest-predation risk (b). Data represent estimated marginal means of log-transformed TBC levels after correction for body condition and sampling date \pm SE. Columns denoted by different symbols are significantly different at the 0.05 level according to an LSD post-hoc test.

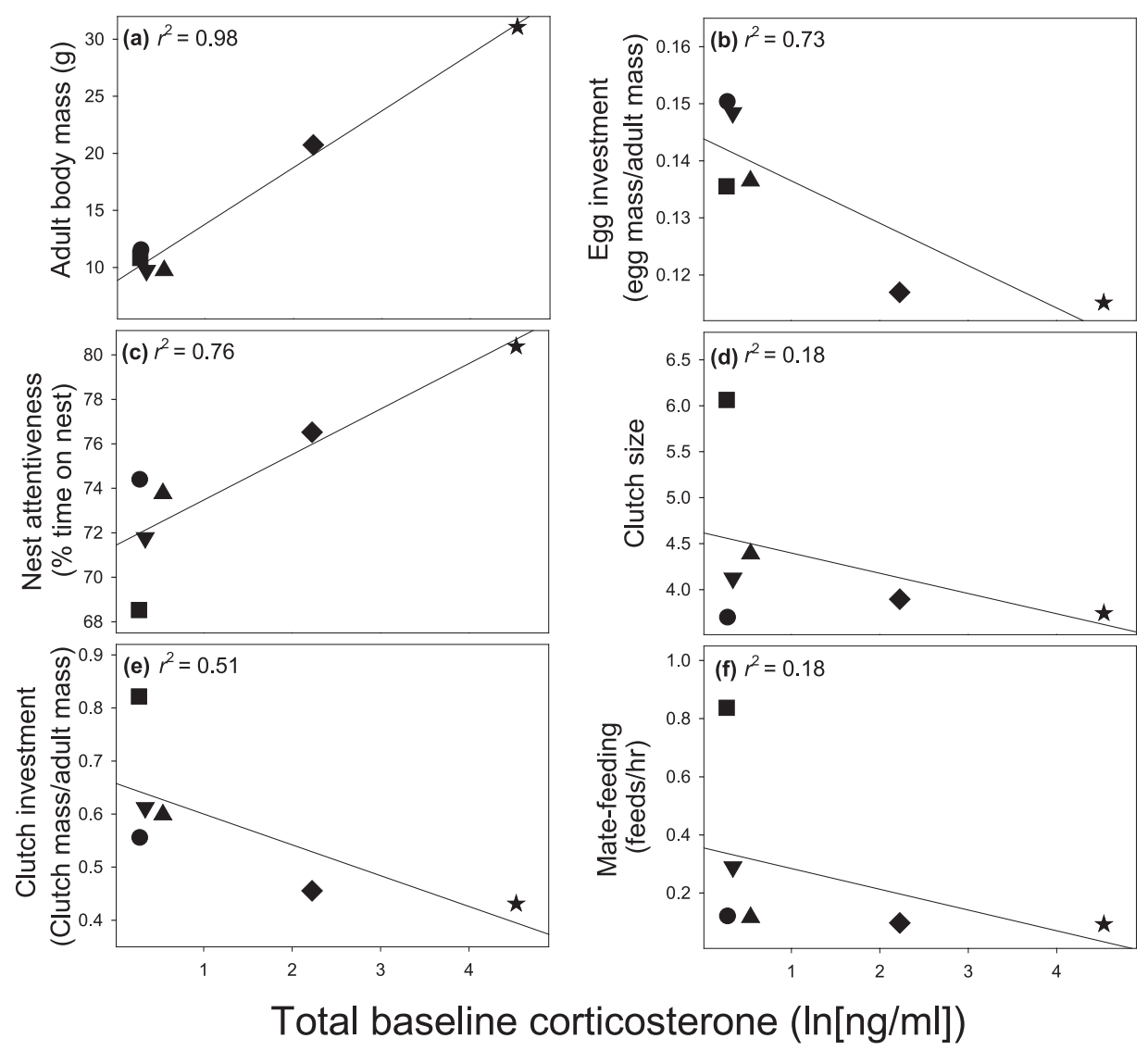

FIGURE 3. Total baseline corticosterone was related to body size but to no other behavioral or life-history trait. Differences among species $(\boldsymbol{\Lambda}$, Orange-crowned Warbler, 12; $\boldsymbol{\nabla}$, Red-faced Warbler, 14; $\bullet$, Cordilleran Flycatcher, 8; $\boldsymbol{\square}$, House Wren, 4; $\bullet$, Gray-headed Junco, 22; . Hermit Thrush, 5) in TBC levels of incubating females were significantly associated with differences in (a) body size but were unrelated to (b) egg investment, (c) nest attentiveness, (d) clutch size, (e) clutch investment, or (f) mate-feeding rate. Data represent estimated marginal means of log-transformed TBC levels after correction for body condition and date of sampling. 
supporting similar findings demonstrating a lack of sensitivity to acute risk of mortality to offspring (Butler et al. 2009).

We found that TBC differences among species did correlate with differences in nest-predation risk (Fig. 2b) and body size (Fig. 3a) but not with the reproductive traits we examined. The positive correlation between body size and TBC is surprising given that smaller species are expected to have higher massspecific metabolic rates and thus higher TBC levels (Bókony et al. 2009, Hau et al. 2010). In our system, however, body size was highly correlated with nest-predation risk $\left(r_{5}=0.845\right.$, $P=0.03)$. Given the limited number of species we examined, the body-size correlation could simply be an indirect reflection of nest-predation risk. Alternatively, it could highlight the strong interaction between body size and nest predation (Biancucci and Martin 2010) and subsequently TBC. Ultimately, while TBC does not appear to act as the physiological mechanism regulating individuals' plastic responses in reproductive strategy to nest-predation risk, it is reasonable that TBC may have evolved as part of a larger life-history strategy that is sensitive to nest predation (Roff 1992, Martin 1995, 2002, Fontaine et al. 2007). Further examination across a broader suite of species is necessary to confirm this relationship.

Given that TBC levels appear sensitive to differences in nest-predation risk across species, our failure to find any relationship among individuals may suggest that instead of changing production and secretion of corticosterone in response to nest-predation risk, individuals may alter bioavailability or sensitivity to corticosterone. We measured TBC concentrations in plasma, which includes both free, unbound corticosterone and corticosterone bound to corticosteronebinding globulin (Breuner and Orchinik 2002). Free corticosterone is considered the biologically active form and thus the form expected to induce changes in reproductive strategies (Breuner et al. 2006). In the European Starling (Sturnus vulgaris), for example, concentrations of free corticosterone in plasma vary with the female's reproductive stage while TBC concentrations remain the same (Love et al. 2004). Alternatively, individuals may regulate receptors at specific targets that influence the expression of reproductive strategies, such as the brain (Breuner and Orchinik 2002), which can influence the sensitivity to TBC without changing TBC levels. Thus corticosterone may influence investment in offspring or the condition of the female in different nest-predation environments, but through the regulation of binding globulins or receptors (Breuner and Orchinik 2002), so its effects may not be apparent in TBC concentrations alone.

Still, our results are surprising not only because previous studies have found correlations within a species between nest-predation risk and TBC concentrations (Scheuerlein et al. 2001, Clinchy et al. 2004) but also because of likely differences between our treatments in adult-food stress. The rate that males supplied females at the nest with additional food and the time females spent off the nest foraging for themselves both increased on removal plots (Fontaine and Martin 2006a). Consequently, on removal plots females were significantly less food limited, which should decrease TBC concentrations (Wingfield 2003, Clinchy et al. 2004). The lack of difference in $\mathrm{TBC}$ concentration between treatments may suggest that the costs of elevated TBC (Sapolsky et al. 2000, Romero 2004, Bonier et al. 2009), even in high-risk, low-food environments, may favor alternative physiological mechanisms for regulating reproductive responses to nest-predation risk.

Selection against elevated TBC may be particularly high during the reproductive period not only because corticosteroids may suppress reproduction (Wingfield and Sapolsky 2003) but also because these costs may be transferred to offspring (Bonier et al. 2009). Recent work demonstrates the transfer of corticosterone from females to eggs (Hayward and Wingfield 2004, Saino et al. 2005, Love et al. 2005, Hayward et al. 2006), and eggs with elevated levels of corticosterone can have reduced hatching success, take longer to hatch, and produce smaller, lower-quality offspring whose stress response is stronger (Eriksen et al. 2003, Hayword and Wingfield 2004, Rubolini et al. 2005, Saino et al. 2005, Hayward et al. 2006, Bonier et al. 2009). These effects, while generally negative, are further compounded in environments with high rates of nest predation. For example, increasing the length of the incubation period increases the risk of nest predation because nest-predation risk compounds daily, but this risk is particularly elevated in environments where nest predation is frequent. The poor quality of offspring is also exaggerated in such environments because parents tend to feed less (Fontaine and Martin 2006a; reviewed in Martin and Briskie 2009), and attempts to compensate by increasing the rate of feeding can lead to increased nest-predation risk (Skutch 1949, Martin et al. 2000). Thus the high costs to offspring of elevated parental TBC may favor alternative physiological mechanisms for regulating reproductive strategies in environments that differ in nest-predation risk, independent of the costs to parents.

TBC levels of individuals did not differ by treatment but decreased with increasing body condition and increased with later date of sampling (Fig. 1), consistent with other examinations of corticosterone (Wingfield et al. 1995, Kitaysky et al. 1999, Adams et al. 2005, Heidinger et al. 2006). While it appears clear that improved body condition reduces TBC levels because individuals in better condition have greater energy reserves and are thus better insulated from environmental stress (Wingfield et al. 1995), it is less clear why TBC levels vary seasonally. In birds, for example, it is widely accepted that TBC levels are elevated during the breeding season (see Romero 2002 for a review), and vary with stage of breeding (Holberton and Wingfield 2003, Adams et al. 2005, Raouf et al. 2006), but whether these differences are due to time-ofyear effects or stage effects has not been clearly established (Heidinger et al. 2006). Here we control for stage and show a 
clear pattern of TBC levels increasing across the breeding season in females of six species of passerines (Fig. 1b).

One explanation for the seasonal pattern is that seasonal increases in competition, predation risk, food limitation, or parasite prevalence could lead to increased chronic stress and thus elevate $\mathrm{TBC}$ levels through the breeding season. In this case, date is simply a correlate of any of several important ecological factors that may invoke an "emergency life history stage" (Wingfield et al. 1998). Alternatively, as the breeding season progresses and the time for other life stages such as molt or migration approaches, TBC may be elevated as either an anticipatory or a reactive response (Gwinner 1996, Styrsky et al. 2004). For example, elevated TBC may act to suppress the initiation of subsequent life stages despite external cues (i.e., photoperiod) and thus allow females to continue incubation behaviors. TBC levels may also increase to prepare a female for the next life stage, particularly molt or migration that requires increased fat deposition, or as a reaction to a diminishing window in which offspring can fledge. Elevated TBC concentrations may improve a female's ability to assimilate energy (Wingfield et al. 1998) and therefore increase her reproductive effort and ultimately her chances of successfully rearing young. Additionally, increases in a female's TBC may lead to increased deposition of corticosterone in eggs and signal the offspring to adjust its phenotypic expression to maximize growth and development. Maternally mediated phenotypic adjustments of development to time of year is widespread among invertebrates and vertebrates and might allow late-born individuals to better cope with a shorter developmental period (Berthold 1996, Gwinner 1996, Styrsky et al. 2004).

Corticosteroids play an important role in regulating behavior, particularly when environmental conditions impose a major threat to an individual (Wingfield et al. 1998). However, the production and secretion of corticosteroids to mediate external costs must be balanced against potential internal costs, which may be particularly important during breeding (Wingfield and Sapolsky 2003). Our findings suggest such a balance, as TBC levels of individuals did not respond to changes in nest-predation risk but did respond to the changing season. Ultimately, the reproductive value of the offspring and the life-history strategy of the species may dictate this balance because in both cases the physiological responses of parents may be in the best interest of the offspring.

\section{ACKNOWLEDGMENTS}

We thank K. Decker, B. Heidinger, A. Chalfoun, D. Emlen, R. Fletcher, J. Maron, D. Reznick, and a multitude of anonymous reviewers for comments and support, and M. Martel, R. Laws, and numerous field assistants for their hard work. We also thank C. Taylor and the Coconino National Forest staff for their support, as well as G. Witmer and the National Wildlife Research Center for the use of their equipment. The Montana Cooperative Wildlife Research Unit is jointly supported by a cooperative agreement of the U.S. Geological Survey; Montana Fish, Wildlife and Parks; the
University of Montana; the U.S. Fish and Wildlife Service; and the Wildlife Management Institute. Any use of trade names is for descriptive purposes only and does not imply endorsement by the U.S. government. This work was supported by funding to TEM from the U.S. Geological Survey's Climate Change Research Program and the National Science Foundation (DEB-9527318, DEB9707598, DEB-9981527 and DEB-0543178), funding to JJF from the American Ornithologists' Union and Sigma Xi, and funding to EA from the Spanish Ministry of Education and Science.

\section{LITERATURE CITED}

Adams, N. J., J. F. Cockrem, G. A. Taylor, E. J. Candy, and J. BRIDGES. 2005. Corticosterone responses of Grey-faced Petrels (Pterodroma macroptera gouldi) are higher during incubation than during other breeding stages. Physiological and Biochemical Zoology 78:69-77.

Barnes, A. I., AND L. PARTRIDGE. 2003. Costing reproduction. Animal Behaviour 66:199-204.

BEgON, M., J. L. HARPER, AND C. R. TownSEND. 1996. Ecology: individuals, populations, and communities, 3rd ed. Blackwell Science, Oxford, England.

Berthold, P. 1996. Control of bird migration. Chapman and Hall, London.

BiAnCuCCI, L., And T. E. Martin. 2010. Can selection on nest size from nest predation explain the latitudinal gradient in clutch size? Journal of Animal Ecology 79:1086-1092.

Bókony, V., A. Z. Lendvai, A. Liker, F. Angelier, J. C. WingFIELD, AND O. CHASTEL. 2009. Stress response and the value of reproduction: are birds prudent parents? American Naturalist 173:589-598.

BReuner, C. W., AND M. ORChINIK. 2002. Beyond carrier proteins: plasma-binding proteins as mediators of corticosteroid action in vertebrates. Journal of Endocrinology 175:99-112.

Breuner, C. W., S. E. Lynn, G. E. Julian, J. M. Cornelius, B. J. Heidinger, O. P. Love, R. S. Sprague, H. Wada, and B. A. Whitman. 2006. Plasma-binding globulins and acute stress response. Hormone and Metabolic Research 38:260-268.

Bonier, F., I. T. Moore, P. R. Martin, ANd R. J. Robertson. 2009. The relationship between fitness and baseline glucocoricoids in a passerine bird. General and Comparative Endocrinology 163:208-213.

Butler, L. K., I. Bisson, T. J. Hayden, M. Wikelski, And L. M. ROMERO. 2009. Adrenocortical responses to offspring-directed threats in two open-nesting birds. General and Comparative Endocrinology 162:313-318.

Clinchy, M., L. Zanette, R. Boonstra, J. C. Wingfield, And J. N. M. Smith. 2004. Balancing food and predation pressure induces chronic stress in songbirds. Proceedings of the Royal Society of London B 271:2473-2479.

Clutton-Brock, T. H. 1991. The evolution of parental care. Princeton University Press, Princeton, NJ.

Cockrem, J. F., AND B. SiLVERIN. 2002. Sight of a predator can stimulate a corticosterone response in the Great Tit (Parus major). General and Comparative Endocrinology 125:248-255.

CYr, N., AND L. M. Romero. 2007. Chronic stress in free-living European Starlings reduces corticosterone concentrations and reproductive success. General and Comparative Endocrinology 151:82-89.

Doligez, B., And J. Clobert. 2003. Clutch size reduction as a response to increased nest predation rate in the Collared Flycatcher. Ecology 84:2582-2588.

Eriksen, M. S., A. Haug, P. A. Torjesen, and M. Bakken. 2003. Prenatal exposure to corticosterone impairs embryonic 
development and increases fluctuating asymmetry in chickens (Gallus gallus domesticus). British Poultry Science 44:690-697.

Fontaine, J. J., AND T.E. Martin. 2006a. Parent birds assess nest predation risk and adjust their reproductive strategies. Ecology Letters 9:428-434.

Fontaine, J. J., AND T. E. Martin. 2006b. Habitat selection responses of parents to offspring predation risk: an experimental test. American Naturalist 168:811-818.

Fontaine, J. J., M. Martel, H. M. Markland, A. M. Niklison, K. L. Decker, And T. E. Martin. 2007. Testing ecological and behavioral correlates of nest predation. Oikos 116:1887-1894.

Ghalambor, C. K., and T. E. Martin. 2001. Fecundity-survival trade-offs and parental risk-taking in birds. Science 292: 494-497.

Ghalambor, C. K., And T. E. Martin. 2002. Comparative manipulation of predation in incubating birds reveals variability in the plasticity of responses. Behavioral Ecology 13:101-108.

Gwinner, E. 1996. Circannual clocks in avian reproduction and migration. Ibis 138:47-63.

Hau, M., R. E. Ricklefs, M. Wikelski, K. A. Lee, and J. D. Brawn. 2010. Corticosterone, testosterone and life-history strategies in birds. Proceedings of the Royal Society B 277:3203-3212.

HaYward, L. S., AND J. C. WingFiELD. 2004. Maternal corticosterone is transferred to avian yolk and may alter offspring growth and adult phenotype. General and Comparative Endocrinology 135:365-371.

Hayward, L. S., J. B. Richarson, M. N. Grogan, and J. C. WingFIELD. 2006. Sex differences in the organizational effects of corticosterone in the egg yolk of quail. General and Comparative Endocrinology 146:144-148.

Heidinger, B. J., I. C. T. Nisbet, And E. D. Ketterson. 2006. Older parents are less responsive to a stressor in a long-lived seabird: a mechanism for increased reproductive performance with age? Proceedings of the Royal Society B 273:2227-2231

Hensler, G. L., AND J. D. Nichols. 1981. The Mayfield method of estimating nesting success: a model, estimators and simulation results. Wilson Bulletin 93:42-53.

Holberton, R. L., AND J. C. Wingfield. 2003. Modulating the corticosterone stress response: a mechanism for balancing individual risk and reproductive success in arctic-breeding sparrows? Auk 120:1140-1150.

Ketterson, E. D., And V. Nolan. 1999. Adaptation, exaptation, and constraint: a hormonal perspective. American Naturalist 154:S4-S25.

Kitaysky, A. S., J. C. Wingfield, and J. F. Piatt. 1999. Dynamics of food availability, body condition and physiological stress response in breeding Black-legged Kittiwakes. Functional Ecology 13:577-584.

LimA, S. L. 2009. Predators and the breeding bird: behavioral and reproductive flexibility under the risk of predation. Biological Reviews 84:485-513.

Love, O. P., C. W. Breuner, F. Vezina, and T. D. Williams. 2004. Mediation of corticosterone-induced reproductive conflict. Hormones and Behavior 46:59-65.

Love, O. P., E. H. Chin, K. E. Wynne-Edwards, And T. D. WiLLIAMS. 2005. Stress hormones: a link between maternal condition and sex-biased reproductive investment. American Naturalist 166:751-766.

Martin, T. E. 1995. Avian life history evolution in relation to nest sites, nest predation and food. Ecological Monographs 65:101-127.

MARTIN, T. E. 1998. Are microhabitat preferences of coexisting species under selection and adaptive? Ecology 79:656-670.
Martin, T. E. 2002. A new view for avian life history evolution tested on an incubation paradox. Proceedings of the Royal Society of London B 269:309-316.

Martin, T. E., AND J. V. BRiskie. 2009. Predation on dependent offspring. A review of the consequences for mean expression and phenotypic plasticity in avian life history traits. The Year in Evolutionary Biology 1168:201-217.

Martin, T. E., AND G. R. Geupel. 1993. Nest-monitoring plots: methods for locating nests and monitoring success. Journal of Field Ornithology 64:507-519.

Martin, T. E., P. R. Martin, C. R. Olson, B. J. Heidinger, and J. J. Fontaine. 2000. Parental care and clutch sizes in North and South American birds. Science 287:1482-1485.

MAYFiELd, H. 1961. Nesting success calculated from exposure. Wilson Bulletin 73:255-261.

MAYFIELD, H. 1975. Suggestions for calculating nest success. Wilson Bulletin 87:456-466.

Peig, J., And A. J. Green. 2009. New perspectives for estimating body condition from mass/length data: the scaled mass index as an alternative method. Oikos 118:1883-1891.

PiAnKA, E. R. 2000. Evolutionary ecology, $6^{\text {th }}$ ed. Benjamin Cummings, San Francisco.

Raouf, S. A., L. C. Smith, M. B. Brown, J. C. Wingfield, And C. R. BROWN. 2006. Glucocorticoid hormone levels increase with group size and parasite load in Cliff Swallows. Animal Behaviour 71:39-48.

RiCKLEFS, R. E. 1969. An analysis of nesting mortality in birds. Smithsonian Contributions to Zoology 9:1-48.

Ricklefs, R. E., AND M. Wikelski. 2002. The physiology/lifehistory nexus. Trends in Ecology and Evolution 17:462-468.

RofF, D. A. 1992. The evolution of life histories theory and analysis. Chapman and Hall, New York.

Romero, L. M. 2002. Seasonal changes in plasma glucocorticoid concentrations in free-living vertebrates. General and Comparative Endocrinology 128:1-24.

Romero, L. M. 2004. Physiological stress in ecology: lessons from biomedical research. Trends in Ecology and Evolution 19:249-255.

Romero, L. M, AND J. M. ReED. 2005. Collecting baseline corticosterone samples in the field: is under 3 min good enough? Comparative Biochemistry and Physiology A 140:73-79.

Rubolini, D., M. Romano, G. Boncoraglio, R. P. Ferrari, R. Martinelli, P. Galeotti, M. Fasola, AND N. Saino. 2005. Effects of elevated egg corticosterone levels on behavior, growth, and immunity of Yellow-legged Gull (Larus michahellis) chicks. Hormones and Behavor 47:592-605.

Saino, N., M. Romano, R. P. Ferrari, R. Martinelli, and A. P. MøLlER. 2005. Stressed mothers lay eggs with high corticosterone levels which produce low-quality offspring. Journal of Experimental Zoology A 303A:998-1006.

SAPOLSKY, R. M., L. M. Romero, AND A. U. MunCK. 2000. How do glucocorticoids influence stress responses? Integrating permissive, suppressive, stimulatory, and preparative actions. Endocrine Review 21:55-89.

Scheuerlein A., T. J. VAN’T HoF, AND E. Gwinner. 2001. Predators as stressors? Physiological and reproductive consequences of predation risk in tropical Stonechats (Saxicola torquata axillaris). Proceedings of the Royal Society of London B 268:1575-1582.

Schoech, S. J., E. D. Ketterson, V. Nolan JR. 1999. Exogenous testosterone and the adrenocortical response in Dark-eyed Juncos. Auk. 116:64-72.

ScHWABL, H. 1995. Individual variation of the acute adrenocortical response to stress in the White-throated Sparrow. Zoology 99:113-120. 
SiLverin, B. 1998. Behavioural and hormonal responses of the Pied Flycatcher to environmental stressors. Animal Behaviour 55:1411-1420.

Sinervo, B., And E. Svensson. 1998. Mechanistic and selective causes of life history trade-offs and plasticity. Oikos 83:432-442.

SKUTCH, A. F. 1949. Do tropical birds rear as many young as they can nourish? Ibis 91:430-455.

Styrsky, J. D., P. Berthold, And W. D. Robinson. 2004. Endogenous control of migration and calendar effects in an intratropical migrant, the Yellow-green Vireo. Animal Behaviour 67:1141-1149.

Wikelski, M., AND S. J. Cooke. 2006. Conservation physiology. Trends in Ecology and Evolution 21:38-46.

Wingfield, J. C. 2003. Control of behavioural strategies for capricious environments. Animal Behaviour 66:807-815.
Wingfield, J. C., K. O'Reilly, And L. Astheimer. 1995. Ecological bases of the modulation of adrenocortical responses to stress in arctic birds. American Zoologist 35:285-294.

Wingfield, J. C., D. L. Maney, C. W. Breuner, J. D. Jacobs, S. LYNN, M. RAMENOFSKY, AND R. D. RichaRdSON. 1998 Ecological bases of hormone-behavior interactions: the "emergency life history stage". American Zoologist 38:191-206.

Wingfield, J. C., AND R. M. SAPOlsky. 2003. Reproduction and resistance to stress: when and how. Journal of Neuroendocrinology 15:711-724.

Zanette, L., J. N. M. Smith, H. van Oort, ANd M. Clinchy. 2003. Synergistic effects of food and predators on annual reproductive success in Song Sparrows. Proceedings of the Royal Society of London B 270:799-803. 